muzyka [Ukrainian Soviet piano music]. Kyiv, 314 p. [in Ukrainian].

3. Kornii, L.P. \& Siuta, B.O. (2014). Ukrainska muzychna kultura. Pohliad kriz viky [Ukrainian music culture. A look through the ages]. Kyiv: Muzychna Ukraina, 592 p. [in Ukrainian].

4. Matsenko, P. (1954). Yakymenko Fedir Stepanovych [Yakimenko Fedir Stepanovich]. Vinnipeg.

5. Mukha, A. (2004). Kompozytory Ukrainy ta ukrainskoi diaspory [Composers of Ukraine and the Ukrainian Diaspora]. Kyiv, 352 p. [in Ukrainian].

6. Novosiadla, I. (2015). Fedir Yakymenko: portret myttsia u dzerkali epokhy [Fedir Yakimenko: portrait of the artist in the mirror of the era]. Musical Ukrainian Studies: European Contex. (Ed.). L. Oparyk. IvanoFrankivsk: Suprun V. P., pp. 112-123. [in Ukrainian].

7. Rudnytskyi, A. (1980). Pro muzyku i muzyk [About music and musicians]. Niu-York - Paryzh - Sidnei Toronto. [in Ukrainian].
8. Ukrainska fortepianna muzyka. Pedahohichnyi repertuar dlia ditei ta yunatstva (2010). Chastyna III. [Ukrainian piano music. Pedagogical repertoire for children and youth. Part III]. (Ed.). O. Kozachuk. Kyiv: Muzychna Ukraina, 184 p. [in Ukrainian].

9. Ukrainska fortepianna muzyka XIX - pochatku XX st. $\mathrm{u}$ konteksti yevropeiskoho romantyzmu (zhanrovo-stylova dynamika) (2017). [Ukrainian piano music of the 19th and early 20th centuries in the context of European romanticism (genre-style dynamics)]. Kyiv: Lira, 224 p. [in Ukrainian].

10. Fortepianni tvory ukrainskykh kompozytoriv: navchalnyi posibnyk (2017). [Piano works of Ukrainian composers: tutorial. Issue 5]. (Ed.). I. Hrynchuk, O. Horbach. Ternopil: Aston, 96 p. [in Ukrainian].

11. Frait, O. V. (2000). Osoblyvosti vtilennia pryntsypu prohramnosti $\mathrm{v}$ ukrainskii fortepiannii muzytsi [Features of the implementation of the principle of programming in Ukrainian piano music]. Extended abstract of candidate's thesis. Kyiv, 18 p. [in Ukrainian].

Стаття надійшла до редакції 06.02.2019

УДК 37.015 .3

DOI:

Світлана Ісаєва, кандидат педагогічних наук, доиент кафедри іноземних мов математичних факультетів Київського національного університету імені Тараса Шевченка

\title{
ДВАНАДЦЯТЬ ТИПІВ РЕАКЦІЙ ЯК ПЕРЕШКОДИ НА ШЛЯХУ ЕФЕКТИВНОЇ ПЕДАГОГІЧНОЇ КОМУНІКАЦЇ̈
}

У статті наголошується на необхідності вивчення світового педагогічного досвіду з метою удосконалення теорії і практики навчально-виховного процесу. Підкреслюється надзвичайна актуальність проблеми ефективної педагогічної комунікації. Згадуються відомі давні мислителі, які вдавалися до комунікаиії в різні часи, та сучасні вітчизняні й зарубіжні науковці, які досліджують дане питання. Особлива увага приділяється науковій спадщині американського психолога і педагога Томаса Гордона. Проаналізовано виокремлені вченим дванадиять типів реакцій, щчо заважають ефективній педагогічній комунікації між вчителем і учнями. nростір.

Ключові слова: педагогічна комунікація; Томас Гордон; реакиія; перешкоди; спілкування; освітній

Jim. 14.

Svitlana Isayeva, Ph. D.(Pedagogy), Associate Professor of the Foreign Languages for Mathematical Faculties Department Taras Shevchenko National University of Kyiv

\section{TWENTY TYPES OF REACTIONSAS OBSTACLES TO EFFECTIVE PEDAGOGICAL COMMUNICATION}

The article emphasizes the necessity of studying the world pedagogical experience in order to improve the theory and practice of the educational process. The urgency of the problem of effective pedagogical communication is accentuated. Famous ancient thinkers, who resorted to communication at different times, and modern domestic and foreign scholars, who are investigating this issue, are mentioned. The analysis of scientific, psychological and pedagogical literature has been carried out. It is stressed that the need to overcome the "crisis of communication" and the necessity to renew the system of upbringing and education have become especially relevant in connection with the entry of Ukrainian young specialists into partnership business contacts with European experts and partners. The importance of enriching the domestic pedagogy with the achievements of foreign scholars because of the processes of globalization of educational space and the interpenetration of pedagogical ideas from different cultures is underlined. Particular attention is paid to the scientific heritage of American psychologist and educator Thomas Gordon. Twelve types of reactions, distinguished by the scientist, which interfere with effective pedagogical communication between a teacher and students, namely: an order; warning, threat; notations, teachings; advice or 


\section{ДВАНАДЦЯТЬ ТИПІВ РЕАКЦЙ ЯК ПЕРЕШКОДИНА ШЛЯХУ ЕФЕКТИВНОЇПЕДАГОПЧНОЇ КОМУНІКАЦІї}

offer to help; examples from personal life, appeal to common sense; disagreement, condemnation; ridicule; explanation, conclusion; praise, showing positive evaluations; sympathy, support; questioning, clarifying the situation; distraction, sarcasm are analyzed. The necessity to take into account the regularities inherent in pedagogical communication for realizing the goals of the educational process is emphasized. Due to Thomas Gordon's researches in the field of communicative pedagogy, the fact, that in the process of pedagogical interaction there are many difficulties which are conditioned to some extent by the disadvantages of teacher training, is confirmed. It is noted that pedagogical communication has its own peculiarities, and therefore, trying to realize the goals of the educational process, each teacher should take into account the patterns inherent in pedagogical communication.

Keywords: pedagogical communication; Thomas Gordon; reaction; obstacles; communication; educational space.

П остановка проблеми у загальному вигляді та її зв'язок із важливими науковими чи практичними завданнями. Вивчення світового педагогічного досвіду, порівняльний аналіз педагогічних систем і теорій різних країн є одним із важливих шляхів удосконалення теорії іпрактики навчально-виховного процесу. Це сприяє глибшому теоретичному та практичному осмисленню державної стратегії у сфері освіти, розвиткові національної школи, іiі інтеграції у світовий педагогічний процес [8].

Надзвичайно актуальною залишається проблема ефективної комунікації, оскільки комунікація $\epsilon$ важливим актом спілкування між людьми, під час якого 3'являється можливість взаємного обміну фактами, ідеями та поглядами. До комунікації вдавалися мислителі різних часів, наприклад, Аристотель, Демосфен, Лісій, Перікл, Платон, Сократ у Давній Греції; Аврелій, Епіктет, Квінтиліан, Лукрецій, Сенека, Філон, Цицерон у Давньому Римі. Серед відомих учених XVI - XIX століть пригадаємо А. Дістервега, Я. Коменського, Дж. Локка, Ж. Руссо.

Аналіз основних досліджень і публікацій, в яких започатковано розв'язання даної проблеми і на які спирасться автор, виділення невирішених раніше частин загальної проблеми, яким присвячується дана стаття. Аналіз наукової та психологопедагогічної літератури свідчить, що у ХХ столітті хід і результати дослідження педагогічної комунікації широко висвітлені упрацях вітчизняних і зарубіжних науковців, серед яких О.О. Бодальов, О.В. Винославська, Н.В. Волкова, В.М. Галузяк, Н.З. Дудник, Е.Х. Еріксон, О.А. Жирун, В.Л. Зливков, В.А. Кан-Калик, Н.В. Кузьміна, А.Х. Маслоу, Г.М. Мешко, С.О. Мусатов, А.А. Реан, В.А. Семиченко, В.А. Сластьонін, Б.Ф. Скіннер, К.Р. Роджерс, Е.Л. Торндайк, М.М. Чепіль, В.В. Ягупов та багато інших [1 - 5; 7; 9 - 13]. На жаль, протягом тривалого часу, поза увагою вчених залишалася наукова спадщина Томаса Гордона, американського психолога, педагога, члена американської школи гуманістичної педагогіки й психології.
Формування мети статті (постановка завдання). Тому, метою нашого дослідження $\epsilon$ ознайомлення читачів з науковими здобутками Томаса Гордона, зокрема 3 виокремленими ним дванадцятьма типами реакцій, що заважають ефективній педагогічній комунікації між вчителем і учнями.

Виклад основного матеріалу дослідження 3 повним обгрунтування отриманих наукових результатів. Розпочнемо 3 того, що необхідність подолати “кризи спілкування” та потреба в поновленні системи виховання й освіти набули особливої актуальності узв'язку з вступом українських молодих спеціалістів у партнерські ділові зв'язки з європейськими спеціалістами та партнерами [6].

Досліджуючи й вивчаючи причини, які заважають конструктивній педагогічній комунікації між вчителем і учнями, Томас Гордон виокремив дванадцять типів реакцій, кожний 3 яких розглянемо окремо.

Отже, до визначених Томасом Гордоном дванадцяти типів реакцій, належать: 1. Наказ, розпорядження; 2. Попередження, погроза; 3. Нотації, повчання; 4. Поради або пропозиція допомоги; 5. Приклади 3 особистого життя, апеляція до здорового глузду; 6. Незгода, критика, засудження; 7.Глузування, висміювання; 8. Роз'яснення, висновок; 9. Похвала, згода, виставляння позитивних оцінок; 10. Співчуття, підтримка; 11. Розпитування, з'ясування ситуації, перехресний допит; 12. Відвернення уваги, сарказм, жарт.

Тепер проаналізуємо кожний тип реакцій окремо:

1. Наказ, розпорядження. Дані висловлювання наштовхують учня на думку, що його почуття нікого не турбують, а тому він повинен поводитися згідно $з$ вимогами вчителя ("Мені байдуже, що ти хочеш пити. Чекай, скільки необхідно”). Крім того вони можуть вказувати на те, що учень вийшов за межі дозволеного (“Не скигли, ти вже дорослий”). Як правило, такі висловлювання викликають острах перед вчителями та призводять до неслухняності й прояву елементів агресії (“Я тобі ще покажу!”) [14, 80].

2. Попередження, погроза. Такі висловлювання 


\section{ДВАНАДЦЯТЬ ТИПІВ РЕАКЦЙ ЯК ПЕРЕШКОДИНА ШЛЯХУ}

ЕФЕКТИВНОЇПЕДАГОПЧНОЇ КОМУНІКАЦЇ̈

нагадують попередні, тобто наказ i розпорядження, однак в них містяться наслідки, котрих може зазнати учень, якщо порушуватиме вимогу вчителя ("Не заважай, бо будеш наказаний!”). Такі висловлювання свідчать про те, що вчитель не поважає інтереси учня і не рахується з його бажаннями (“Якщо не встигнеш все виконати, будеш робити, поки не зробиш”). Дані висловлювання викликають у дитини острах і змушують їі відчувати свою підлеглість (“Якщо ти не зміниш свою поведінку, я викликатиму твоїх батьків”). Так як такі попередження породжують ворожість, в результаті в учнів з'являється бажання вчинити саме так, як їх просили не робити, з метою перевірити, чи реалізує вчитель свої погрози [14, $80-81]$. В інших випадках ці висловлювання викликають байдужість, і учні реагують на них, або погрози, словами: "Мені байдуже, що буде".

3. Нотації, повчання. Ці висловлювання викликають у учнів відчуття сторонньої влади, підсилене острахом того, що вони “повинні” діяти наказаним їм чином. Томас Гордон наголошував, що це змушує учнів реагувати на слова "повинен” або “зобов’язаний” неслухняністю, задля того, щоб захистити свою позицію. Такі висловлювання наштовхують учнів на думку, що вчитель не довіряє їм (“Поводьтеся належним чином!”) i породжують у учнів відчуття провини, переконуючи їх у тому, що вони “погані”. (“Ти не повинен так поводитися, бо нам буде соромно за тебе і за нашу школу"). Як правило, у подібних випадках учні починають думати, що вчитель не вірить в їхню здатність дотримуватися власної думки і власних цінностей (“Ти повинен прислуховуватися до старших!”) [14, 81 - 82].

4. Поради або пропозиція допомоги. Дані висловлювання свідчать про невпевненість вчителів у здатності учнів вирішувати свої проблеми. Безперервні поради позбавляють учнів самостійності, роблячи їх залежними від вчителів, і змушують удаватися до допомоги авторитетів $[14,82]$.

5. Приклади з особистого життя, апеляція до здорового глузду. Як правило, вислуховуючи повчання, учні відчувають свою недосконалість і підлеглість. Заклики вчителів до здорового глузду і наведення ними прикладів 3 власного досвіду породжують в учнів бажання наполягати на своєму. Як і дорослі, учні не відчувають задоволення, коли їх критикують чи сварять, а тому намагаються відстояти свою позицію словами: “Я правий, а ви неправі, і я це доведу вам!”. Слід відмітити, що напучення ніколи не вважалися особливо ефективними в педагогіці, оскільки спричиняють шкоду, породжуючи роздратування і злість. Учні починають вважати, що вчителі до них несправедливі, і припиняють прислухатися до них. Вони, навіть, несамовито і відчайдушно намагаються спростувати наведені вчителем "приклади": "Вам цього не зрозуміти. Ви надто старі для цього" [14, 82 - 83].

6. Незгода, критика, засудження. Такі висловлювання найбільше переконують учнів, що вони недостойні і погані. Оскільки вчителі і батьки - самі важливі дорослі в житті учнів, їх самосприйняття залежить від того, що вони про них кажуть. Негативні оціночні висловлювання знижують самооцінку учнів. У свою чергу, вчителі, котрі користуються негативними оціночними висловлюваннями, найчастіше скаржаться на відсутність поваги з боку учнів [14, 83 - 84].

7. Глузування, висміювання. Ці висловлювання містять негативну оцінку і критику, а тому руйнують уявлення учня про себе. Як правило, на такі висловлювання учні реагують зарозумілістю та зухвалістю. Вчителі, учиняючи тиск на учня, використовують ці висловлювання, але також залишаються розчарованими [14, $84-85]$.

8. Роз'яснення, висновок. Дані висловлювання сприймаються учнями як те, що вчитель здогадується про причини їх поведінки (“Ти так поводишся, тому що намагаєшся привернути до себе увагу”). Слід підкреслити, що якщо психоаналіз вчителя виявиться правильним, то він може налякати учнів, і вони почуватимуться незахищеними. Якщо ж аналіз виявиться помилковим, як буває частіше, то учень може почати обурюватися через помилкове звинувачення. Висловлювання типу “Я тебе наскрізь бачу” взагалі позбавляють учнів будь-якого бажання продовжувати розмову. Вони, навпаки, переконують їх у тому, що ділитися 3 вчителем своїми проблемами ризиковано [14, 84 - 86].

9. Похвала, згода, виставляння позитивних оцінок. Вчителі підтверджують силу негативних оцінок, але часто не можуть прийняти факт, що похвала також може мати негативні наслідки. Позитивна оцінка може зародити в учневі роздратування у випадках, коли вона не співпадає 3 його власним іміджем. Учні вважають, що такі позитивні висловлювання є спробою змусити їх робити те, що хоче вчитель. На думку учнів, якщо вчитель може необгрунтовано використати позитивну оцінку, то аналогічно він може використати й негативну. До того ж, припинення використання похвали у класі часто інтерпретується учнями як осуд; адже, звикнувши до постійних похвал, учні починають потребувати iii, а часом, навіть, вимагати [14, 85 - 87]. 


\section{ДВАНАДЦЯТЬ ТИПІВ РЕАКЦЙ ЯК ПЕРЕШКОДИНА ШЛЯХУ ЕФЕКТИВНОӤПЕДАГОГІЧНОӤ КОМУНІКАЦЇ}

10. Співчуття, підтримка. Під час роботи 3 проблемними учнями, на перший погляд, такі висловлювання можуть здаватися корисними, хоча, насправді, вони викликають в учня відчуття, що вчитель його зовсім не розуміє. Томас Гордон вважав, що так відбувається, тому що вчителям не подобаються прояви в учнів сильних негативних емоцій, і вони будь-яким чином намагаються уникати подібних проблемних ситуацій. Словесні переконання чи підтримка у такі моменти засвідчують спроби вчителя вплинути на учнів так, щоб вони припинили хвилюватися (“Хіба варто хвилюватися? Все вирішиться саме собою. Завтра буде краще"). Після такого "співчуття" учні перестають вірити вчителям, так як сприймають їх дії за спробу вплинути на них. Співчугтя та підтримка, що часто використовуються для пригнічення сильних проявів емоцій, заважають відвертій бесіді, тому що учні бачать, що вчитель не намагається розв'язати їх проблему, а лише хоче змінити їхнє ставлення до неї [14, 86 - 87].

11. Розпитування, 3'ясування ситуації, перехресний допит. Існує низка питань, які можуть сприйматися учнями як результат відсутності довіри чи як підозрілість вчителя по відношенню до них ("Ти вчора ввечері робив домашнє завдання?”, “Як довго ти це вчив? Всього годину? Чи не мало часу ти витратив на це завдання?”). У подібних питаннях учні часто чують загрозу для себе - особливо, через нерозуміння причини постановки такого питання вчителем, а тому відповідають своїм питанням: “А навіщо Вам треба це знати?”. Такі ситуації виникають у випадках, коли вчитель намагається дізнатися більше, ніж учні хочуть сказати [14, 87 - 89].

12. Відвернення уваги, сарказм, жарт. Такі висловлювання наштовхують учня на думку, що вчитель не поважає його почуття. Висміювання й передражнювання, як правило, ображають, відштовхують або змушують учня стати замкненим і відлюдним. Оскільки учні серйозно ставляться до розмови про свої проблеми, вони хочуть бути почутими і зрозумілими, а тому не довіряють вчителям, які застосовують сарказм і жарти, й не розглядають їх як помічників [14, 88 - 89].

Висновки 3 даного дослідження i перспективи подальших розвідок у даному напрямку. Отже, у зв'язку з процесами глобалізації освітнього простору та взаємопроникненням педагогічних ідей з різних культур, важливе значення має збагачення вітчизняної педагогіки здобугками зарубіжних учених.

Дослідження Томаса Гордона в області комунікативної педагогіки свідчать, що у процесі педагогічної взаємодії виникають багато труднощів, які, на переконання вченого, певною мірою обумовлені недоліками підготовки вчителів. Слід пам'ятати, що педагогічне спілкування має свої особливості, а тому, намагаючись реалізувати цілі навчально-виховного процесу, кожен вчитель зобов' язаний враховувати закономірності, властиві педагогічному спілкуванню.

Слід підкреслити, що порівняльно-педагогічні дослідження на сучасному етапі розвитку української національної школи та педагогіки дадуть можливість виявити, що є національними особливостями освіти, а що - загальним надбанням усього цивілізованого світу та необхідною основою будь-якої національної школи. Важливість порівняльно-педагогічних досліджень зумовлена також значним місцем, яке вони посіли в зарубіжній педагогічній науці [8].

\section{ЛІТЕРАТУРА}

1. Винославська О.В., Зливков В.Л. Нормовідповідність і рольова ідентифікація у професіональній діяльності викладача школи. Актуальні проблеми психології. Том 1. Соціальна психологія. Психологія управління. Організаційна психологія. К.: Ін-т психології ім. Г.С. Костюка АПН України, 2002. С. 63-67.

2. Волкова Н.П. Професійно-педагогічна комунікація: теорія, технологія, практика: монографія. Д.: Вид-во ДНУ, 2005. 304 с.

3. Галузяк В.М. Сутність і структура педагогічної компетентності вчителя. Наукові записки Вінницького держ. пед. ун-ту ім. Михайла Коцюбинського. Серія: Педагогіка і психологія. 2016. Вип. 48. С. 37-46.

4. Жирун О.А. Компетенції викладача в умовах формування професійної ідентичності. Вісник Національного технічного університету України “КПІ”: Філософія. Психологія. Педагогіка. 2009 № 3. Ч. 1. С. 99-103.

5. Зливков В.Л. Самоідентифікація в педагогічній комунікації. К.: Український центр політичного менеджменту, 2005. 144 с. [Бібліотека журналу “Соціальна психологія”].

6. Ісаєва С.Д. Комунікативна педагогіка Томаса Гордона: посібник. К.: ПанТот, 2014. $168 \mathrm{c.}$

7. Ісаєва С.Д. Рекомендації Томаса Гордона щодо гармонізації діяльності вчителя у школі. Молодь і ринок. 2013. № 5. С.160-164.

8. Красовицький М.Ю. Концепція порівняльної педагогіки в умовах реформування освіти в Україні: Порівняльна педагогіка: методологічні 
орієнтири українських компаративістів: хрестоматія / авторський колектив. К: Педагогічна думка, 2015. 176 с.

9. Мешко Г.М. Вступ до педагогічної професії: навч. посібник. К.: Академвидав, 2012. 200 с.

10. Мусатов С.О. Вчитель як суб'єкт педагогічної комунікації. Діалогічна взаємодія у навчально-виховному процесі загальноосвітньої школи. К.: ІЗМН, 1997. С. 62-75.

11. Семиченко В.А. Психологія педагогічної діяльності: навч. посіб. К.: Вища школа, 2004. $335 \mathrm{c}$.

12. Чепіль М.М., Дудник Н.3. Педагогічні технології: навч. посіб. К.: Академвидав, 2012. 224 с.

13. Ягупов В.В. Педагогіка: навч. посібник В.В. Ягупов. К.: Либідь, 2002. 560 с.

14. Gordon Th. Teacher Effectiveness Training. The Program Proven to Help Teachers Bring Out the Best in Students of All Ages. New York: Three rivers press, 2003. $344 \mathrm{p}$.

\section{REFERENCES}

1. Vynoslavska, O.V. \& Zlyvkov, V.L. (2002). Normovidpovidnist $i$ rolova identyfikatsiia $u$ profesionalnii diialnosti vykladacha shkoly [Conformity and role identification in the professional activity of the school teacher]. Current problems of psychology. Volume 1. Social Psychology. Psychology of management. Organizational psychology. Kyiv: Institute of Psychology named after G.S. Kostiuk, Academy of Pedagogical Sciences of Ukraine, pp. 6367. [in Ukrainian].

2. Volkova, N.P. (2005). Profesiino-pedahohichna komunikatsiia: teoriia, tekhnolohiia, praktyka: monohrafiia [Professional and pedagogical communication: theory, technology, practice: monograph]. Dnipro: vydavnytstvo DNU, 304 p. [in Ukrainian].

3. Haluziak, V.M. (2016). Sutnist i struktura pedahohichnoi kompetentnosti vchytelia [Essence and structure of teacher's pedagogical competence]. Scientific notes of Vinnytsia state pedagogical university named after Michael Kotsyubinsky. Series: Pedagogy and Psychology, No. 48, pp. 37-46. [in Ukrainian].

4. Zhyrun, O.A. (2009). Kompetentsii vykladacha $v$ umovakh formuvannia profesiinoi identychnosti [Teacher competences in the conditions of formation of professional identity]. Bulletin of the National Technical University of Ukraine "KPI": Philosophy.
Psychology. Pedagogy, No. 3, Part 1, pp. 99-103. [in Ukrainian].

5. Zlyvkov, V.L. (2005). Samoidentyfikatsiia v pedahohichnii komunikatsii [Self-identification in pedagogical communication]. Kyiv: Ukrainian Center for Political Management. Library of the journal "Social Psychology", 144 p. [in Ukrainian].

6. Isaieva, S.D. (2014). Komunikatyvna pedahohika Tomasa Hordona: posibnyk [Thomas Gordon's communicative pedagogy: manual]. Kyiv: PanTot, 168 p. [in Ukrainian].

7. Isaieva, S.D. (2013). Rekomendatsii Tomasa Hordona shchodo harmonizatsii diialnosti vchytelia $u$ shkoli [Thomas Gordon's recommendations on harmonizing the teacher's activities at school]. Youth and market, No. 5, pp.160-164. [in Ukrainian].

8. Krasovytskyi, M.U. (2015). Kontseptsiia porivnialnoi pedahohiky $v$ umovakh reformuvannia osvity v Ukraini: Porivnialna pedahohika: metodolohichni oriientyry ukrainskykh komparatyvistiv: khrestomatiia [Concept of comparative pedagogy in terms of education reforming in Ukraine: Comparative pedagogy: methodological benchmarks of Ukrainian comparativists: textbook]. Kyiv: Pedagogical Thought, 176 p. [in Ukrainian].

9. Meshko, H.M. (2012). Vstup do pedahohichnoi profesii: navchalnyi posibnyk [Introduction to the pedagogical profession: teaching manual]. Kyiv: Akademvidav, 200 p. [in Ukrainian].

10. Musatov, S.O. (1997). Vchytel yak subiekt pedahohichnoi komunikatsii (Dialohichna vzaiemodiia u navchalno-vykhovnomu protsesi zahalnoosvitnoi shkoly) [Teacher as a subject of pedagogical communication (Dialogical interaction in the educational process of a secondary school)]. Kyiv: IZMN, pp. 62-75. [in Ukrainian].

11. Semychenko, V.A. (2004). Psykholohiia pedahohichnoi diialnosti: navchalnyi posibnyk [Psychology of pedagogical activity: teaching manual]. Kyiv: Higher School, 335 p. [in Ukrainian].

12. Chepil, M.M. \& Dudnyk, N.Z. (2012). Pedahohichni tekhnolohii: navchalnyi posibnyk [Pedagogical technologies: teaching manual]. Kyiv: Academic Edition, 224 p. [in Ukrainian].

13. Yahupov, V.V. (2002). Pedahohika: navchalnyi posibnyk [Pedagogy: teaching manual]. Kyiv: Lybid, 560 p. [in Ukrainian].

14. Gordon, Th. (2003). Teacher Effectiveness Training. The Program Proven to Help Teachers Bring Out the Best in Students of All Ages. New York: Three rivers press, 344 p. [in English].

Стаття надійшла до редакції 21.02.2019

G58080

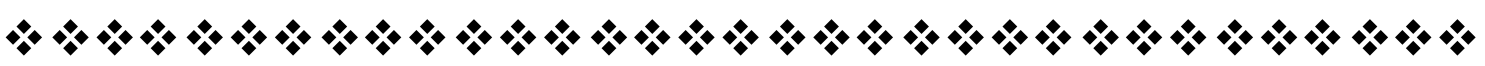

